\title{
Predictive Factors in the Incidence of Cirrhosis in Chronic Hepatitis B Virus Infections
}

\author{
Seyed Moayed Alavian, ${ }^{1}$ Mohammad Hadi Imanieh, ${ }^{2}$ and Mohammad Hossein Imanieh ${ }^{1,2,}$ \\ ${ }^{1}$ Baqiyatallah Research Center for Gastroenterology and Liver Diseases, Baqiyatallah University of Medical Sciences, Tehran, IR Iran \\ ${ }^{2}$ Gastroenterohepatology Research Center, Shiraz University of Medical Sciences, Shiraz, IR Iran \\ "Corresponding author: Mohammad Hossein Imanieh, Baqiyatallah Research Center for Gastroenterology and Liver Diseases, Baqiyatallah University of Medical Sciences, \\ Tehran, IR Iran. Tel/Fax: +98-2188067114, E-mail: imanieh.mh@gmail.com
}

Received 2015 November 17; Revised 2016 March 10; Accepted 2016 March 11.

\begin{abstract}
Background: Hepatitis B virus (HBV) is among the leading causes of liver cirrhosis worldwide. Predictors of cirrhosis in Iranian chronic hepatitis B (CHB) patients are yet to be clearly identified.

Objectives: Evaluating the predictive factors of liver cirrhosis in CHB.

Patients and Methods: A longitudinal study was conducted during 1995 - 2014 on all CHB patients who were referred to Tehran hepatitis center, Tehran, Iran. The patients were assessed during periodic visits through medical history and laboratory data. Logistic regression analyses were used to determine predictors of cirrhosis.

Results: Two hundred thirty-seven CHB patients were followed for an average duration of 10.6 years, and 41 of these patients developed cirrhosis. The incidence rate of cirrhosis was 2.82/100 person-years. Univariate analyses determined 9 out of 17 factors as significant predictors of outcome in CHB patients. Age of $\geq 45$ years, positive hepatitis D virus (HDV), negative HBeAg, platelet count of $<150\left(\times 10^{9}\right) / \mathrm{L}$, and HBV DNA level of $\geq 2,000 \mathrm{IU} / \mathrm{mL}$ were identified as significant independent predictors of liver cirrhosis in multiple logistic analyses.

Conclusions: Five predictive factors that are simple and easy to measure may be used as parameters for the prediction of liver cirrhosis in $\mathrm{CHB}$ patients.
\end{abstract}

Keywords: Chronic Hepatitis B, Liver Cirrhosis, Prognosis, Longitudinal Study

\section{Background}

Hepatitis B virus (HBV) infections are a common global problem, despite effective vaccination and anti-viral therapies. HBV infection is the tenth leading cause of death in the world (1), with more than 350 million people affected by chronic hepatitis $\mathrm{B}$ ( $\mathrm{CHB}$ ) (2). CHB, along with liver cirrhosis and hepatocellular carcinoma (HCC), results in 0.5 - 1.2 million deaths each year (3). In Iran, 1.5 million people are infected with HBV, among whom $15 \%$ - $40 \%$ are predisposed to liver cirrhosis and/or HCC in the future (4). Genotype D is the most common genotype in Iran and is associated with the precore mutation and HBV e antigen (HBeAg)-negative $\mathrm{CHB}$ (5-7).

Many host and viral factors can affect the natural course of HBV infection. HBeAg, serum levels of HBV DNA, HBV genotype $(C>B$; D > A), co-infection with hepatitis $C$ virus (HCV) or hepatitis D virus (HDV), as well as comorbidities, including smoking and alcohol abuse, have been well-documented as risk predictors of cirrhosis and HCC in CHB patients (8). Identification of high-risk CHB carriers seems to be an acceptable strategy for prevention, or for the early diagnosis of liver cirrhosis, enabling further therapeutic management.

\section{Objectives}

The aim of this study was to determine the probable risk factors for developing cirrhosis in Iranian CHB patients.

\section{Patients and Methods}

\subsection{Type of Study and Research Environment}

This longitudinal study was performed from 1995 to 2014 on a group of 270 patients (aged $13-78$ years) who were diagnosed with HBsAg over a period of longer than six months. The cases were selected from the Tehran hepatitis center (THC), a referral center and the outpatient clinic of Baqiyatallah research center for gastroenterology and liver diseases, Baqiyatallah University of Medical Sciences, Tehran, Iran. Patients with positive results for HBsAg and who had completed at least five years of follow-up were included in this study. The exclusion criteria were cirrhosis 
as a first presentation, immunocompromised status, concurrent HCV, HIV infection or other liver diseases (autoimmune hepatitis, Wilson's disease, hemochromatosis, and $\alpha$-1-antitrypsin deficiency), or refusal to participate in the survey. Informed consent was obtained from all patients.

\subsection{Follow-Up}

The patients were assessed by one observer six months after their first visit, and then annually. The patients' past medical histories were investigated for the presence of diabetes mellitus (DM), alcohol consumption, smoking, and opium addiction. In addition, a family history of liver disease, including carrier state of HBV, chronic HBV, cirrhosis, and HCC, were recorded. During each visit, we evaluated liver function tests, including serum levels of aspartate aminotransferase (AST) and alanine aminotransferase (ALT), as well as serum albumin, total bilirubin, prothrombin time (PT), fasting blood glucose (FBS), platelet count, and serological HBV markers. Viral markers (HBsAg, antiHBs, HBeAg, and anti-HBe) were measured using the ELISA method (9). All of the included patients were assumed to be infected with HBV genotype D. Serum HBV DNA levels were quantitatively assessed with Cobas Amplicor and Cobas Taqman from Roche Diagnostics. The lower limit of detection is 200 copies/mL (38 IU/mL) for Amplicor and 30 copies (6 IU/mL) for Taqman. Validation and calibration of the laboratory equipment were approved by authorized sections.

The baseline presentation of the patients was determined according to the natural history of $\mathrm{CHB}$ infection, which is divided into 4 phases: 1) immune tolerance, 2) immune clearance (also referred to as immune active), 3) inactive carrier state, and 4) HBeAg-negative CHB (also known as reactivation) (10-12). The characteristics of the aforementioned phases are summarized in Table 1.

The diagnosis of liver cirrhosis was based on ultrasonographic findings supported by liver histology, thrombocytopenia, or direct observation of esophageal varices on upper gastrointestinal endoscopy. For HCC, the diagnosis was made when a patient met one of the following two criteria: a non-invasive criterion using multidetector CT scan/dynamic contrast-enhanced MRI showing typical hypervascularity in the arterial phase with washout in the portal vein or delayed phases, or a pathologic biopsy compatible with malignancy $(13,14)$.

Eligible patients were treated according to the latest guidelines for HBV treatment. The study protocol was approved by the ethics committee of Baqiyatallah University of Medical Sciences (Code 340/5/5904 number 91 on $11 / 15 / 14)$.

\subsection{Data Analysis}

Univariate and multiple logistic regression analyses were performed, yielding regression coefficients, odds ratios (ORs), and P values. The response or outcome variable of the analyses was the presence/absence of liver cirrhosis. Univariate analyses were initially performed to identify potential determinants of outcome of all variables assumed to be associated with liver cirrhosis. Laboratory parameters were categorized into two different groups based on defined normal ranges. Chi-square was used to determine the statistical significance of the relationship between the independent and dependent variables (cirrhotic and noncirrhotic). After exclusion of those variables with no prognostic significance, appropriate potential variables were determined for multivariate analysis. Backward stepwise logistic regression was then recruited to identify predictive factors (with $\alpha>0.05$ taken as a level of entry and exclusion) that were correlated with our outcome. The data were statistically analyzed using the IBM SPSS statistics software, version 22.0 (SPSS Inc., Chicago, IL, USA). P < 0.05 was considered significant.

\section{Results}

\subsection{Patient Details}

After the exclusion of 33 patients, a total of $237 \mathrm{CHB}$ patients were recruited, of whom 41 (17.3\%) developed liver cirrhosis (Figure 1). The median and mean duration of follow-up of the cirrhotic patients were 12 years (range 5 18 ) and 11.4 years $(S D=2.6)$, respectively. The incidence rates of cirrhosis and HCC were 2.82/100 and 0.75/100 personyears, respectively. A positive family history of HBV infection in at least one first-degree relative was present in $54.9 \%$ $(\mathrm{n}=130)$ of the patients, and the majority of these did not present with liver cirrhosis $(\mathrm{P}=0.037)$.

The baseline presentations of the patients are shown in Table 1. Forty-two, 45, 44, and 106 patients initially presented in phases 1 through 4 , respectively, of CHB.

\subsection{Factors Associated With the Development of Liver Cirrhosis}

Univariate analyses determined 9 out of 17 factors as significant predictors of liver cirrhosis in CHB patients (Tables 2 and 3). Liver cirrhosis was significantly higher in older patients $(\geq 50$ years $)$ and diabetic patients $(P<0.001$ and $\mathrm{P}=0.001$, respectively). There was a significant association between liver cirrhosis and HDV infection $(\mathrm{P}<$ 0.001) and HCC $(\mathrm{P}<0.001)$. The prevalence of HDV in $\mathrm{CHB}$ patients was $10.1 \%$. Older $\mathrm{CHB}$ patients had significantly higher rates of HDV infection $(\mathrm{P}<0.001)$ and HBeAg negativity $(\mathrm{P}<0.001)$. 
Table 1. Phases of CHB Infection

\begin{tabular}{lllll}
\hline & Phase 1: Immune Tolerance & Phase 2: Immune Clearance & Phase 3: Inactive Carrier State & Phase 4: HBeAg-Negative CHB \\
\hline ALT & Normal & Elevated & Normal & Elevated \\
HBV DNA & $\begin{array}{l}\text { Elevated, typically }>1 \text { million } \\
\text { IU } / \mathrm{mL}\end{array}$ & Elevated $\geq 20,000 \mathrm{IU} / \mathrm{mL}$ & $\begin{array}{l}\text { Low or undetectable }<2,000 \\
\mathrm{IU} / \mathrm{mL}\end{array}$ & Elevated $\geq 2,000 \mathrm{IU} / \mathrm{mL}$ \\
HBeAg & Positive & Positive & Negative & Normal or mild inflammation \\
Liver histology & Normal or mild hepatitis & $\begin{array}{l}\text { Moderate or severe } \\
\text { necroinflammation and fibrosis }\end{array}$ & & Moderate to severe inflammation \\
& & &
\end{tabular}

Table 2. [Part 1] Univariate Analysis of Parameters in CHB Patients

\begin{tabular}{|c|c|c|c|c|c|}
\hline Parameters & Overall $(n=237)$ & $\operatorname{Cirrhotic}(n=41)$ & Non-Cirrhotic $(n=196)$ & Odds Ratio (95\% CI) & P Value \\
\hline Age, $y$ & & & & $10.892(4.096-28.969)$ & $<0.001^{\mathrm{a}}$ \\
\hline$<45$ & 123 & 5 & 118 & & \\
\hline$\geq 45$ & 114 & 36 & 78 & & \\
\hline $\operatorname{Sex}\left(M: F^{b}\right)$ & 171:66 & $30: 11$ & 141:55 & $1.064(0.499-2.27)$ & 0.873 \\
\hline Follow-Up, y & & & & & 0.06 \\
\hline Mean $\pm S D$ & $10.6 \pm 2.9$ & $11.4 \pm 2.6$ & $10.5 \pm 2.9$ & & \\
\hline Median (range) & $11(5-19)$ & $12(5-18)$ & $10(5-19)$ & & \\
\hline Smoker $^{c}$ & 21 & 5 & 16 & $1.562(0.538-4.537)$ & 0.412 \\
\hline $\mathbf{D M}^{\mathbf{c}}$ & 46 & 16 & 30 & $3.541(1.693-7.409)$ & $0.001^{\mathrm{a}}$ \\
\hline Alcohol $^{\mathrm{c}}$ & 21 & 3 & 18 & $1.281(0.359-4.568)$ & 0.703 \\
\hline Steatosis $^{c}$ & 45 & 9 & 36 & $1.25(0.549-2.847)$ & 0.595 \\
\hline Negative HBeAg ${ }^{c}$ & 87 & 5 & 82 & $5.179(1.949-13.765)$ & $0.001^{\mathrm{a}}$ \\
\hline $\mathrm{HDV}^{\mathrm{c}}$ & 24 & 15 & 9 & $11.987(4.765-30.158)$ & $<0.001^{\mathrm{a}}$ \\
\hline $\mathrm{HCC}^{\mathrm{c}}$ & 12 & 8 & 4 & $11.636(3.315-40.85)$ & $<0.001^{\mathrm{a}}$ \\
\hline \multicolumn{6}{|l|}{ Positive family history } \\
\hline HBV & 130 & 16 & 114 & - & - \\
\hline Cirrhosis & 25 & 6 & 19 & - & - \\
\hline HCC & 3 & 0 & 3 & - & - \\
\hline
\end{tabular}

The laboratory data of the patients were monitored during follow-up. Patients who developed liver cirrhosis had significantly higher median AST levels and higher median bilirubin levels during follow-up compared to noncirrhotic patients. There was a meaningful correlation between lower median platelet levels and higher median HBV DNA levels in the sera of CHB patients, and the development of liver cirrhosis. P values are presented in (Table 1).

There was no association between liver cirrhosis and sex, smoking, alcohol consumption, or liver steatosis, or with serum albumin, ALT, PT, or FBS levels.
In this study, an age of $\geq 45$ years, HDV positivity, HBeAg negativity, a platelet count of $<150\left(\times 10^{9}\right) / \mathrm{L}$, and an HBV DNA level of $\geq 2,000 \mathrm{IU} / \mathrm{mL}$ were identified as significant independent predictors of liver cirrhosis (Table 4). Other factors implicated in the univariate analysis did not reach statistical significance in multiple logistic regression analyses. 
Table 3. [Part 2] Univariate Analysis of Parameters in CHB Patients

\begin{tabular}{|c|c|c|c|c|c|}
\hline Parameters $^{\mathrm{a}}$ & Overall $(n=237)$ & $\operatorname{Cirrhotic}(n=41)$ & Non-Cirrhotic $(n=196)$ & Odds Ratio (95\% CI) & P Value \\
\hline Albumin, $\mathbf{g} / \mathbf{L}^{\mathbf{b}}$ & & & & $1.037(0.284-3.788)$ & 0.956 \\
\hline$<35^{c}$ & 17 & 3 & 14 & & \\
\hline$\geq 35$ & 209 & 38 & 171 & & \\
\hline AST, $\mathbf{U} / \mathbf{L}$ & & & & $3.77(1.816-7.825)$ & $<0.001^{\mathrm{d}}$ \\
\hline$<40^{\mathrm{c}}$ & 189 & 24 & 165 & & \\
\hline$\geq 40$ & 48 & 17 & 31 & & \\
\hline $\mathbf{A L T}, \mathbf{U} / \mathbf{L}$ & & & & $1.251(0.609-2.567)$ & 0.542 \\
\hline$<45$ & 152 & 28 & 124 & & 0.542 \\
\hline$\geq 45^{\mathrm{c}}$ & 85 & 13 & 72 & & \\
\hline Total bilirubin, $\mu \mathrm{mol} / \mathrm{L}$ & & & & $3.227(1.405-6.275)$ & $0.006^{\mathrm{d}}$ \\
\hline$<15^{\mathrm{c}}$ & 206 & 30 & 176 & & \\
\hline$\geq 15$ & 31 & 11 & 20 & & \\
\hline PT, s & & & & $2.6(0.878-7.699)$ & 0.085 \\
\hline$<13^{\mathrm{c}}$ & 47 & 4 & 43 & & \\
\hline$\geq 13$ & 190 & 37 & 153 & & \\
\hline Platelet count, $\times 10^{9} / \mathrm{L}$ & & & & $10.216(4.821-21.651)$ & $<0.001^{\mathrm{d}}$ \\
\hline$<150$ & 51 & 25 & 26 & & \\
\hline$\geq 150^{\mathrm{c}}$ & 186 & 16 & 170 & & \\
\hline $\operatorname{FBS}(\mathrm{mg} / \mathrm{dL})^{\mathrm{e}}$ & & & & $1.623(0.42-6.275)$ & 0.483 \\
\hline$<126^{\mathrm{c}}$ & 223 & 38 & 185 & & \\
\hline$\geq 126$ & 12 & 3 & 9 & & \\
\hline HBV DNA level, IU/mL & & & & $4.372(2.136-8.952)$ & $<0.001^{\mathrm{d}}$ \\
\hline$<2,000^{\mathrm{c}}$ & 189 & 20 & 169 & & \\
\hline$\geq 2,000$ & 44 & 19 & 25 & & \\
\hline
\end{tabular}

${ }^{a}$ Laboratory parameters were categorized into two different groups based on defined normal ranges.

${ }^{\mathrm{b}}$ Data were not available for 11 patients.

${ }^{\mathrm{c}}$ Reference level.

${ }^{\mathrm{d}}$ Statistically significant $(\mathrm{P}$ value $<0.05)$

${ }^{\mathrm{e}}$ Data were not available for 2 patients.

${ }_{\mathrm{f}}$ Data were not available for 4 patients.

Table 4. Multiple Logistic Regression Analysis of Parameters in CHB Patients ${ }^{\mathrm{a}}$

\begin{tabular}{|c|c|c|c|c|c|}
\hline Variable & $\beta$ & $\mathbf{S E}^{*}(\beta)$ & OR & Cl95 & PValue \\
\hline Age ( $\geq 45$ vs. $<45$ years $)$ & 1.624 & 0.58 & 5.073 & $1.629-15.799$ & 0.005 \\
\hline HDV (positive vs. negative) & 2.487 & 0.674 & 12.026 & $3.209-45.068$ & $<0.001$ \\
\hline HBeAg (negative vs. positive) & 1.352 & 0.666 & 3.867 & $1.049-14.251$ & 0.042 \\
\hline Platelet count $\left(<150\right.$ vs. $\left.\geq 150 \times 10^{9} / \mathrm{L}\right)$ & 1.066 & 0.503 & 2.903 & $1.083-7.777$ & 0.034 \\
\hline HBV DNA level ( $\geq 2,000$ vs. $<2,000 \mathrm{IU} / \mathrm{mL}$ ) & 2.255 & 0.516 & 9.538 & $3.471-26.211$ & $<0.001$ \\
\hline
\end{tabular}

Abbreviations: CI95, 95\% confidence interval; OR, odds ratio; and SE, standard error.

${ }^{\mathrm{a}} \mathrm{A}$ total of 233 patients were used for the multivariate logistic analysis. 


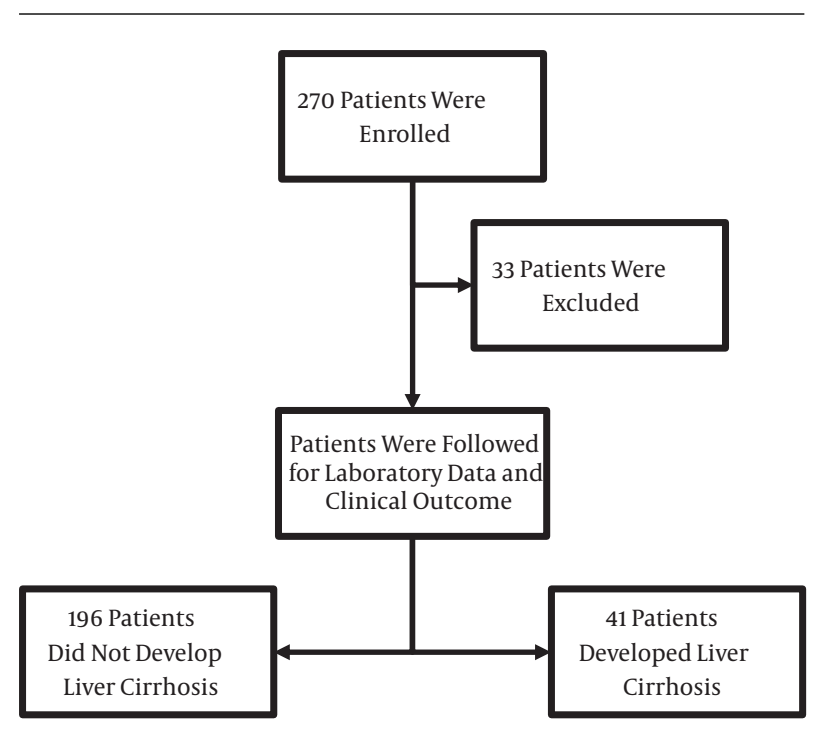

Figure 1. Flow Chart of the Study Participants

\section{Discussion}

During a mean period of ten years of follow-up, 237 CHB patients were monitored for probable predictors of liver cirrhosis. Most of the patients were male and under 45 years old ( $n=171$ and $n=123$, respectively). The incidence rates of cirrhosis and HCC in CHB patients were 2.82/100 and $0.75 / 100$ person-years, respectively, which is comparable to the similar data from Iran and other countries (8, $14,15)$. HBV genotype D is the most predominant genotype in Iranian subjects suffering from CHB (6). Genotype D may be associated with higher rates of hepatoma, posttransplant recurrence, and mortality compared with genotype A (16).

Our results suggest that five different parameters represent significant risk factors for the development of liver cirrhosis in CHB patients. In the last few decades, the mean age at infection with HBV has increased in Iran as a result of the establishment of a national hepatitis B vaccination program in 1993 and improved immunity of young children against HBV infection $(17,18)$. Older CHB patients are more likely to develop cirrhosis during follow-up, as seen in similar studies from East Asian and European countries (15, 1923).

In this study, $\mathrm{HDV}$ prevalence was $10.1 \%$ in $\mathrm{CHB}$ patients, which is in the range of the results of other studies from our country and around the world $(24,25)$. HDV positivity is the most significant risk factor for the incidence of cirrhosis in CHB patients. Co-infection with HDV worsens the CHB patient's condition. HDV-infected patients are more likely to present with serious complications compared to
HBV patients without HDV, and the relative risk of developing cirrhosis in HDV-infected patients seems to be doubled $(8,26)$. The later development of liver cirrhosis in HDVinfected patients decreases the probability of survival to $49 \%$ and $40 \%$ at 5 and 10 years, respectively (27). It is important to screen $\mathrm{CHB}$ patients for HDV for better management of concurrent infections, and for close observation for the early diagnosis of subsequent complications.

We demonstrated that cirrhosis was four times more common in HBeAg-negative patients. East Asian countries show the same pattern for the development of cirrhosis in HBeAg-negative patients (28-31). HBeAg-negative patients are usually older than those who are HBeAg-positive, which may be due to the fact that HBeAg-negative chronic hepatitis represents a late stage in the natural course of $\mathrm{CHB}$ infection, and HBeAg-negative patients have a longer duration of liver disease $(8,32,33)$. In addition, many mutations (such as precore G1896A stop codon mutation or double nucleotide mutations [A1762T/G1764A] in basal core promoter) are associated with the HBeAg-negative CHB phase. These mutations, alone or in combination, not only can result in loss of HBeAg synthesis but can also promote progressive liver disease, including cirrhosis (34). However, the overall incidence rates of cirrhosis in HBeAg-negative patients in western countries are higher than in Asian countries $(8,35)$. The inclusion of a large proportion of HBeAg-positive carriers presenting in the immune tolerant phase of $\mathrm{CHB}$ infection can provide a valuable clue to why East Asian studies demonstrate lower rates of cirrhosis in HBeAg-negative patients (8). Accordingly, substantial progression of fibrosis in the liver histology after transition from the immune tolerant phase to the immune clearance phase occurs as a result of immune-mediated liver damage (36). Of note, genotype D is associated with HBeAgnegative disease and a more severe disease course compared to other genotypes. HBeAg seroconversion occurs at higher rates and at younger ages among patients with genotype D compared to other genotypes $(5,7,37)$. Despite the fact that they are independent risk factors for the development of liver cirrhosis, advanced age and negative HBeAg status were strongly correlated with extensive liver fibrosis in the present study (Figure 2).

In the present study, we were able to demonstrate that thrombocytopenia had a substantial impact on the development of cirrhosis in CHB patients. Despite the fact that platelet sequestration in the spleen and decreased production of thrombopoietin in the liver contributes to thrombocytopenia in liver cirrhosis, experimental data show that thrombocytopenia per se might be implicated in the progression of liver fibrosis (38-40). Mohamadnejad et al. also reported that a low platelet count was an independent risk factor for noticeable fibrosis in CHB patients (41). This 


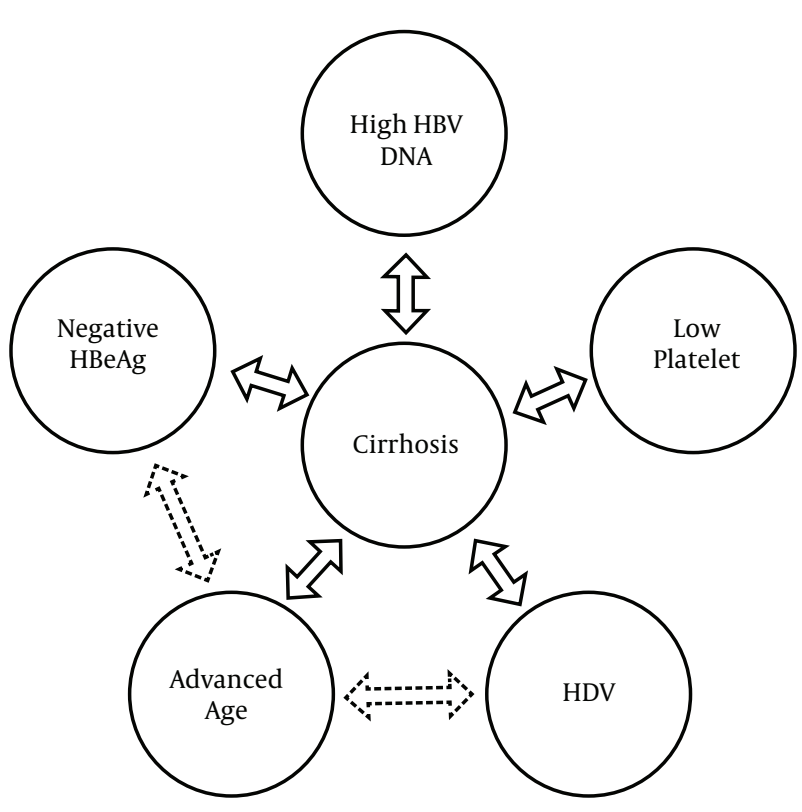

Figure 2. Correlation Between Risk Factors of Cirrhosis

implies a two-sided correlation between thrombocytopenia and progression to liver cirrhosis.

The current study revealed that higher serum HBV DNA levels $(\geq 2000 \mathrm{IU} / \mathrm{mL}$ ) strongly correlated with progression to liver cirrhosis. Iloeje et al. have shown that with increasing HBV DNA levels in CHB patients, the risk of cirrhosis increases (20). In a similar study by Wong et al. (42), the odds ratios for cirrhosis began to increase significantly when serum HBV DNA was > 2,000 IU/mL in HBeAgnegative CHB patients. Despite the fact that serum HBV DNA levels had no significant correlation with liver histology, an HBV DNA level of 4,000 IU/mL could predict considerable liver fibrosis with a sensitivity of $82 \%$ and specificity of $70 \%$ in HBeAg-negative patients $(41,43,44)$. Therefore, close monitoring of the serum HBV DNA level is recommended due to the risk of CHB progression to liver cirrhosis with elevated levels (45). On the other hand, genotype D patients had the lowest chance of sustained response to interferon therapy, regardless of serum HBV DNA or ALT levels (46).

The strong points of this study were the 10 years of patient follow-up, the relatively appropriate sample size, and complete laboratory data. However, a limitation of the present investigation was that we studied the patients at a single center. In addition, the univariate analyses identified 8 out of 17 factors as unsuitable predictors of liver cirrhosis in CHB patients. This may be due to actual insignificant differences or an insufficient sample size.

In conclusion, significant predictors of liver cirrhosis, such as an age of $\geq 45$ years, HDV positivity, HBeAg negativity, a platelet count of $<150\left(\times 10^{9}\right) / \mathrm{L}$, and an HBV DNA level of $\geq 2,000 \mathrm{IU} / \mathrm{mL}$, may provide valid information for further diagnostic and therapeutic decisions in CHB patients. These data are simple to gather, easy to measure, and costeffective for the prediction of liver cirrhosis.

\section{Acknowledgments}

The authors would like to thank Prof. Mehrdad Askarian for his kind cooperation in the preparation of this article. Special thanks are also expressed to the staff at Tehran hepatitis center for their help and support, and to all of the participating patients.

\section{Footnote}

Authors' Contribution: Seyed Moayed Alavian: study conception and design, analysis and interpretation of data. Mohammad Hadi Imanieh: analysis and interpretation of data. Mohammad Hossein Imanieh: all parts of the investigation.

\section{References}

1. Alavian SM. Hepatitis B virus infection in Iran; Changing the epidemiology. ARCHCID. 2010;5(1):51-61.

2. Liaw YF, Chu CM. Hepatitis $\mathrm{B}$ virus infection. Lancet. 2009;373(9663):582-92. doi: 10.1016/s0140-6736(09)60207-5.

3. Lavanchy D. Hepatitis B virus epidemiology, disease burden, treatment, and current and emerging prevention and control measures. J Viral Hepat. 2004;11(2):97-107. [PubMed:14996343].

4. Alavian SM, Hajarizadeh B, Ahmadzad-Asl M, Kabir A, Lankarani KB. Hepatitis B Virus Infection in Iran: A Systematic Review. Hepat Mon. 2008;8(4):281-94.

5. Croagh CM, Desmond PV, Bell SJ. Genotypes and viral variants in chronic hepatitis B: A review of epidemiology and clinical relevance. World J Hepatol. 2015;7(3):289-303. doi: 10.4254/wjh.v7.i3.289. [PubMed: 25848459].

6. Bahramali G, Sadeghizadeh M, Amini-Bavil-Olyaee S, Alavian SM, Behzad-Behbahani A, Adeli A, et al. Clinical, virologic and phylogenetic features of hepatitis B infection in Iranian patients. World J Gastroenterol. 2008;14(35):5448-53. [PubMed: 18803358].

7. Sunbul M. Hepatitis B virus genotypes: global distribution and clinical importance. World J Gastroenterol. 2014;20(18):5427-34. doi: 10.3748/wjg.v20.i18.5427. [PubMed: 24833873].

8. Fattovich G, Bortolotti F, Donato F. Natural history of chronic hepatitis B: special emphasis on disease progression and prognostic factors. J Hepatol. 2008;48(2):335-52. doi: 10.1016/j.jhep.2007.11.011. [PubMed: 18096267].

9. Yuen MF, Yuan HJ, Wong DK, Yuen JC, Wong WM, Chan AO, et al. Prognostic determinants for chronic hepatitis B in Asians: therapeutic implications. Gut. 2005;54(11):1610-4. doi: 10.1136/gut.2005.065136. [PubMed: 15871997].

10. European Association For The Study Of The L. EASL clinical practice guidelines: Management of chronic hepatitis B virus infection. J Hepatol. 2012;57(1):167-85. doi: 10.1016/j.jhep.2012.02.010. [PubMed: 22436845]. 
11. Liaw YF, Kao JH, Piratvisuth T, Chan HL, Chien RN, Liu CJ, et al. AsianPacific consensus statement on the management of chronic hepatitis B: a 2012 update. Hepatol Int. 2012;6(3):531-61. doi: 10.1007/s12072-0129365-4. [PubMed: 26201469].

12. Terrault NA, Bzowej NH, Chang KM, Hwang JP, Jonas MM, Murad MH AASLD guidelines for treatment of chronic hepatitis B. Hepatology. 2016;63(1):261-83. doi: 10.1002/hep.28156. [PubMed: 26566064].

13. El-Serag HB. Hepatocellular carcinoma. NEngl J Med. 2011;365(12):111827. doi: 10.1056/NEJMra1001683. [PubMed: 21992124].

14. Sali S, Alavian SM, Foster GR, Keyvani H, Mehrnoosh L, Mohammadi N Influencing Factors on the Outcome and Prognosis of Patients With HBV Infction: Seven Years Follow-up. Hepat Mon. 2013;13(7):8743. doi: 10.5812/hepatmon.8743.

15. Lee MH, Yang HI, Liu J, Batrla-Utermann R, Jen CL, Iloeje UH, et al. Prediction models of long-term cirrhosis and hepatocellular carcinoma risk in chronic hepatitis B patients: risk scores integrating host and virus profiles. Hepatology. 2013;58(2):546-54. doi: 10.1002/hep.26385. [PubMed: 23504622].

16. Liu CJ, Kao JH, Chen DS. Therapeutic implications of hepatitis B virus genotypes. Liver Int. 2005;25(6):1097-107. doi: 10.1111/j.14783231.2005.01177.x. [PubMed: 16343058].

17. Alavian SM, Fallahian F, Lankarani KB. The changing epidemiology of viral hepatitis B in Iran. J Gastrointestin Liver Dis. 2007;16(4):403-6. [PubMed: 18193122].

18. Askarian M, Mansour Ghanaie R, Karimi A, Habibzadeh F. Infectious diseases in Iran: a bird's eye view. Clin Microbiol Infect. 2012;18(11):10818. doi: 10.1111/1469-0691.12021. [PubMed: 23033964].

19. Poh Z, Goh BB, Chang PE, Tan CK. Rates of cirrhosis and hepatocellular carcinoma in chronic hepatitis $B$ and the role of surveillance: a 10-year follow-up of 673 patients. Eur J Gastroenterol Hepatol. 2015;27(6):638-43. doi: 10.1097/MEG.0000000000000341. [PubMed: 25831135].

20. Iloeje UH, Yang HI, Su J, Jen CL, You SL, Chen CJ, et al. Predicting cirrhosis risk based on the level of circulating hepatitis B viral load. Gastroenterology. 2006;130(3):678-86. doi: 10.1053/j.gastro.2005.11.016. [PubMed: 16530509].

21. Park BK, Park YN, Ahn SH, Lee KS, Chon CY, Moon YM, et al. Long term outcome of chronic hepatitis B based on histological grade and stage. J Gastroenterol Hepatol. 2007;22(3):383-8. doi: 10.1111/j.14401746.2007.04857.x. [PubMed:17295771].

22. Sagnelli E, Stroffolini T, Mele A, Imparato M, Sagnelli C, Coppola N, et al. Impact of comorbidities on the severity of chronic hepatitis B at presentation. World J Gastroenterol. 2012;18(14):1616-21. doi: 10.3748/wjg.v18.i14.1616. [PubMed: 22529690]

23. Cadranel JF, Lahmek P, Causse X, Bellaiche G, Bettan L, Fontanges $\mathrm{T}$, et al. Epidemiology of chronic hepatitis B infection in France: risk factors for significant fibrosis-results of a nationwide survey. Aliment Pharmacol Ther. 2007;26(4):565-76. doi: 10.1111/j.13652036.2007.03400.x. [PubMed: 17661760].

24. Amini N, Alavian SM, Kabir A, Saiedi Hosseini SY, Aalaei Andabili SH. Clinical Features and Seroepidemiology of Anti-HDV Antibody in patients With Chronic Hepatitis B Virus Infection in Iran: A Meta-Analysis. Hepat Mon. 2011;11(12):960-7. doi: 10.5812/kowsar.1735143X.805. [PubMed: 22368679].

25. Alavian SM, Alavian SH. Hepatitis D Virus Infection; Iran, Middle East and Central Asia. Hepat Mon. 2005;5(4):137-43.

26. Gu XH, Chen Z, Dai RY, Zhang ML, Tang HM, Chen LB, et al. Analysis on the clinical features of $507 \mathrm{HDV}$-infected patients. Cell Biochem Biophys. 2014;70(3):1829-32. doi: 10.1007/s12013-014-0137-8. [PubMed: 25085619].

27. Rosina F, Conoscitore P, Cuppone R, Rocca G, Giuliani A, Cozzolongo $\mathrm{R}$, et al. Changing pattern of chronic hepatitis D in Southern Europe. Gastroenterology. 1999;117(1):161-6. [PubMed: 10381923].

28. Hsu YS, Chien RN, Yeh CT, Sheen IS, Chiou HY, Chu CM, et al. Long-term outcome after spontaneous HBeAg seroconversion in patients with chronic hepatitis B. Hepatology. 2002;35(6):1522-7. doi: 10.1053/jhep.2002.33638. [PubMed: 12029639].

29. Chu CM, Hung SJ, Lin J, Tai DI, Liaw YF. Natural history of hepatitis B e antigen to antibody seroconversion in patients with normal serum aminotransferase levels. Am J Med. 2004;116(12):829-34. doi: 10.1016/j.amjmed.2003.12.040. [PubMed:15178498].

30. Lin SM, Yu ML, Lee CM, Chien RN, Sheen IS, Chu CM, et al. Interferon therapy in $\mathrm{HBeAg}$ positive chronic hepatitis reduces progression to cirrhosis and hepatocellular carcinoma. J Hepatol. 2007;46(1):45-52. doi: 10.1016/j.jhep.2006.08.021. [PubMed: 17107734].

31. Jang JW, Lee YC, Kim MS, Lee SY, Bae SH, Choi JY, et al. A 13-year longitudinal study of the impact of double mutations in the core promoter region of hepatitis B virus on HBeAg seroconversion and disease progression in patients with genotype $C$ chronic active hepatitis. J Viral Hepat. 2007;14(3):169-75. doi: 10.1111/j.1365-2893.2006.00788.x. [PubMed: 17305882].

32. Hadziyannis SJ, Papatheodoridis GV. Hepatitis B e antigen-negative chronic hepatitis B: natural history and treatment. Semin Liver Dis. 2006;26(2):130-41. doi: 10.1055/s-2006-939751. [PubMed: 16673291].

33. Zarski JP, Marcellin P, Leroy V, Trepo C, Samuel D, Ganne-Carrie $\mathrm{N}$, et al. Characteristics of patients with chronic hepatitis $\mathrm{B}$ in France: predominant frequency of HBe antigen negative cases.J Hepatol. 2006;45(3):355-60. doi: 10.1016/j.jhep.2006.03.007. [PubMed: 16750585].

34. Kao JH, Chen PJ, Chen DS. Recent advances in the research of hepatitis B virus-related hepatocellular carcinoma: epidemiologic and molecular biological aspects. Adv Cancer Res. 2010;108:21-72. doi: 10.1016/B978-0-12-380888-2.00002-9. [PubMed: 21034965].

35. Mazzella G, Saracco G, Festi D, Rosina F, Marchetto S, Jaboli F, et al. Long-term results with interferon therapy in chronic type B hepatitis: a prospective randomized trial. Am J Gastroenterol. 1999;94(8):224650. doi: 10.1111/j.1572-0241.1999.01300.x. [PubMed: 10445557].

36. Croagh CM, Lubel JS. Natural history of chronic hepatitis B: phases in a complex relationship. World J Gastroenterol. 2014;20(30):10395-404. doi: 10.3748/wjg.v20.i30.10395. [PubMed: 25132755].

37. Ansari N, Makvandi M, Samarbaf-Zadeh AR. Hepatitis B virus Genotyping Among Patients With Cirrhosis. Jundishapur J Microbiol. 2015;8(3):e14571. doi: 10.5812/jjm.14571. [PubMed: 25964845].

38. Hayashi H, Beppu T, Shirabe K, Maehara Y, Baba H. Management of thrombocytopenia due to liver cirrhosis: a review. World J Gastroenterol. 2014;20(10):2595-605. doi: 10.3748/wjg.v20.i10.2595. [PubMed: 24627595].

39. Iannacone M, Sitia G, Isogawa M, Marchese P, Castro MG, Lowenstein PR, et al. Platelets mediate cytotoxic T lymphocyte-induced liver damage. Nat Med. 2005;11(11):1167-9. doi: 10.1038/nm1317. [PubMed: 16258538].

40. Kodama T, Takehara T, Hikita H, Shimizu S, Li W, Miyagi T, et al. Thrombocytopenia exacerbates cholestasis-induced liver fibrosis in mice. Gastroenterology. 2010;138(7):2487-98. doi: 10.1053/j.gastro.2010.02.054. [PubMed: 20206174] 2498 e1-7.

41. Mohamadnejad M, Montazeri G, Fazlollahi A, Zamani F, Nasiri J, Nobakht $\mathrm{H}$, et al. Noninvasive markers of liver fibrosis and inflammation in chronic hepatitis B-virus related liver disease. Am J Gastroenterol. 2006;101(11):2537-45. doi: 10.1111/j.1572-0241.2006.00788.x. [PubMed: 17029616].

42. Wong GL, Wong VW, Choi PC, Chan AW, Chim AM, Yiu KK, et al. Evaluation of alanine transaminase and hepatitis B virus DNA to predict liver cirrhosis in hepatitis B e antigen-negative chronic hepatitis B using transient elastography. Am J Gastroenterol. 2008;103(12):3071-81. doi: 10.1111/j.1572-0241.2008.02157.x. [PubMed:19086958].

43. Karbasi A, Bafandeh B, Alavian SM, Saburi A. Can Viral Load Predict Liver Histology in Patients With Chronic Hepatitis B?. Int J Travel Med Global Health. 2015;3(1):19-21. doi:10.20286/ijtmgh-030119.

44. Shao J, Wei L, Wang H, Sun Y, Zhang LF, Li J, et al. Relationship between hepatitis B virus DNA levels and liver histology in patients with chronic hepatitis B. World J Gastroenterol. 2007;13(14):2104-7. 
[PubMed: 17465456].

45. Zacharakis G, Koskinas J, Kotsiou S, Tzara F, Vafeiadis N, Papoutselis $\mathrm{M}$, et al. The role of serial measurement of serum HBV DNA levels in patients with chronic $\mathrm{HBeAg}(-)$ hepatitis B infection: association with liver disease progression. A prospective cohort study.J Hepatol. 2008;49(6):884-91. doi: 10.1016/j.jhep.2008.06.009. [PubMed:
18674840]

46. Buster EH, Hansen BE, Lau GK, Piratvisuth T, Zeuzem S, Steyerberg EW, et al. Factors that predict response of patients with hepatitis B e antigen-positive chronic hepatitis B to peginterferon-alfa. Gastroenterology. 2009;137(6):2002-9. doi: 10.1053/j.gastro.2009.08.061. [PubMed: 19737568]. 